\title{
Islamic Banking Products, Services and Objectives: Perspectives of Shariah Supervisors and Regulators
}

\author{
MUHAMMAD AQIB ALI \\ Ph.D Scholar, University of Management and Technology, Lahore. \\ Email: email_aqib@yahoo.com \\ Tel: +923216609790
}

TALAT HUSSAIN

Assistant Professor, University of Management and Technology, Lahore.

Email: talat.hussain@umt.edu.pk

Tel: +923074447808

\begin{abstract}
The study is aimed at assessing the opinions of vital Islamic banking stakeholders including members of various Islamic banking Shariah Supervisory Boards (SSBS) and pertinent personnel from Pakistan's central bank - The State Bank of Pakistan (SBP). The research analyzes the percepts of respondents regarding various aspects relevant to Islamic banking (IB) products, service and objectives. The paper employs qualitative research approach in analyzing the Shariah and regulatory experts' viewpoints regarding Islamic banking. The study is conducted using semi-structured interviews of twelve Shariah supervisors and nine SBP staff members serving in the Islamic banking department and Islamic banking focus groups in the regional/field offices of the State Bank of Pakistan. The study is of pioneering nature involving qualitative research design and inclusion of two of the most significant stakeholder groups from the Islamic banking sector of Pakistan who have not been included in the past studies regarding Islamic banking perceptions. The research findings highlighted that Shariah objectives are top priority of Islamic banks as per the views expressed by members of Shariah boards of various banks while in opinion of Islamic banking regulators, Islamic banks' major concern is to achieve their business objectives.
\end{abstract}

Keywords: Islamic Banking, Islamic Finance, Pakistan, Products, Perceptions, Shariah Compliance.

\section{Introduction}

Islamic banking is now a global phenomenon with a proven track record of success in not only the Muslim countries, but also in non-Muslim states, IB is a reckoning sector in Muslim-minority jurisdictions including UK, Europe, and Africa. According to the IFSB Report of 2019, global Islamic banking accounts for $72 \%$ of all Islamic financial services with approximately 1.57 Trillion USD assets. There are a total of 1389 Islamic financial institutions worldwide (Thomson Reuters, 2018) operating in more than 110 countries (Ayub, 2017) and out of these, 505 financial institutions are Islamic banks including the Islamic windows of conventional banks.

There are currently five dedicated Islamic banks operating in Pakistan including Meezan Bank, Al-Baraka Bank, Bank Islami, Dubai Islamic Bank and MCB Islamic Bank. The number of conventional banks Islamic banking divisions/windows operating in the country is 17 with 2979 Islamic banking branches (SBP, 2019). The market share of Islamic banking assets and deposits in Pakistan's overall banking industry is $15.2 \%$ and $16.9 \%$ respectively (SBP, 2020). 
There have been several studies undertaken on the subject of Islamic banking perceptions including the ones by Gerrard and Cunningham (1997), Metawa and Almossawi (1998), Ahmad and Haron (2002), Dusuki (2007), Dusuki and Abdullah (2007a), Dusuki (2008), Loo (2010), Rustam et al. (2011), Lee and Shakir (2011), Saeed et al. (2012), Riaz (2014), Ringim and Yussof (2014), Buchari et al (2015), Khan and Ramzan (2015), Akhtar et al. (2016), Shah et al. (2016), Majeed and Zainab (2017), Aqib and Hussain (2017), Ali and Hassan (2017), Lujja and Hassan (2018), Belwal and Maqbali (2019) to name a few, but there is quite a scarce research on exploring and analyzing the perspectives of two key stakeholder groups which are included in this study to fill the gap i.e. the percepts of Shariah scholars and Islamic banking (IB) industry regulators. Although there are a few studies to assess and evaluate the perspectives of Shariah scholars/supervisors including those Shariah experts who are members of SSBs of Islamic banking and conventional financial institutions offering Islamic finance offerings; however, there is absence of research studies regarding the opinions and viewpoints of regulators about Islamic banking paradigm. This study is a pioneering work in this regard, as it incorporates the responses of industry regulators along with Shariah supervisors.

\section{Literature Review}

There are several studies conducted to assess the percepts of various stakeholder groups about various aspects of Islamic banking including the studies aimed at exploring the perceptions of customers including the studies by Gerrard and Cunningham, 1997; Metawa and Al-Mossawi,1998; Lee and Shakir, 2011; Echchabi and Olaniyi, 2012; Saeed et al., 2012; Fada and Webekwa, 2012; Ringim and Yussof, 2014; Ghani et al., 2015; Akhtar et al., 2016; Jose et al., 2018; studies analyzing the opinions of bankers including researches by Awan and Bukhari, 2011; Buchari et al, 2015; Shah et al. 2016, Majeed and Zainab 2017, Riaz et al. 2017, Aqib and Hussain, 2017; Ali and Hassan, 2017; Ali et al., 2018; Majeed and Zainab, 2018; studies to evaluate the viewpoints of corporate customers including the research investigations by Ahmad and Haron, 2000; Rustam et al., 2011; and the analysis of perspectives of Shariah experts involved with IB industry in the study undertaken by Ayedh and Echchabi in 2015.

The diverse studies undertaken in the past, on the assessment of stakeholders' perceptions included various aspects of Islamic banking. Some of these studies, in the context of this research, include the ones on Islamic banking ideals and objectives (Dusuki 2007, Dusuki 2008, Khan and Ramzan 2015); several other studies focused Islamic banking products/services quality and customer satisfaction (Khan et al., 2007; Abdullah and Kassim, 2009; Awan et al., 2011; Butt and Aftab, 2013; Ringim, 2014; Belwal and Maqbali, 2019).

Although the Islamic banking initiative has shown a widespread and increasing popularity with the passage of time after (Ahmed, 2014), yet the products and offerings of Islamic banks have come under criticism from various stakeholders especially the customers who are of the opinion that most IB products and services are a replica of conventional banking products with apparently insignificant differences (Khan, 2010; Butt et al., 2011). This is one of the areas, aptly highlighted by Ahmed (2011) who asserted that Islamic banks must endeavor to develop Shariah based products instead of only focusing on Shariahcompliant and pseudo Islamic products. Besides the critique regarding Islamic banking products and services, this is also a fact that Islamic banks have provided a range of Shariah-compliant products and services to cater to the needs of their customers which include various offerings that may be categorized into three major categories in terms of product structures: namely partnership-based products, trade-based products, and lease-based products. The partnership-based products that are mainly structured on the basis of Mudaraba and Musharaka concepts (Usmani, 1999), are typically applied and adopted to offer depository and investment products of Islamic banks for their customers involving income generating savings accounts, investment instruments and short-term profit sharing checking accounts (Iqbal and Mirakhor, 2007). The trade-based offerings involve chiefly the financing products based on the Islamic sale concepts of Murabaha, Salam and Istisna (Hassan and Mahlknecht, 2011; Aqib, 2014). The trade-based modes are frequently employed to facilitate and finance the procurement of raw materials, assets, 
equipment, and trade commodities. The lease-based products are formulated on the basis of Islamic leasing variant termed Ijarah. The leasing-based Ijarah is used to generally finance the consumer products and vehicles.

Elbeck and Dedoussis (2010) described that customer preferences of Islamic banks are based upon a variety of factors which may differ from country to country and Shome et al. (2018) also elucidated several factors that customers ponder while dealing with an Islamic bank. Besides the fact that religious beliefs are a major reason to transact with Islamic banks as concluded in different studies (Ringim, 2014; Souiden and Rani, 2015); yet this is also a fact concluded in several past studies that religion is not the single motive of Islamic banking customers (Erol and EI-Bdour, 1989; Awan and Bukhari, 2011). Apart from the religious element, customers are also interested in other banking features to select an Islamic bank including customer convenience, cost competitiveness, location, service quality, bank's image and reputation. Shariah compliance being directly pertinent to the religious motive is one of the chief factors that the customers consider while deciding about which bank to choose, as highlighted by Abduh and Omar (2012); Shakir and Lee, (2012); Echchabi et al., (2016); and Ltifi et al., (2016). As per the findings of Shome et al. (2018), Shariah compliance is especially more important for the customers in the countries and locations with predominantly Muslim populations and they consider the element of compliance with Shariah and its principles as most significant while dealing with the Islamic banks. Butt and Aftab (2013) suggested that both religious as well as functional beliefs play a role in shaping the consumer attitudes and perceptions towards Islamic banking. For instance as already mentioned some of the factors other than religion and Shariah compliance of products including relative price of products, service convenience, and bank's reputation have a significant contribution towards customers' patronization of Islamic banks as highlighted by the studies by Dusuki and Abdullah (2007a); Ringim and Yussof (2014), and Buchari et al (2015). There is much emphasis laid upon the Islamic banks', being pinned upon an ethical baseline, to offer services to the customers that are not only unique but also are quality-driven in comparison to the conventional counterparts offerings which are based solely on price (Wilson, 2005; Saidi, 2009). In general, the perceptions of both stakeholder segments including the customers and bankers working with the Islamic banks are favorable towards the philosophy and practices of Islamic banking, and there is a great potential for IB products and services to expand their market share. This is imperative to promote greater awareness and understanding about IB offerings which would not only help the IB industry to flourish more but would also create a more positive image about IB products and processes among its existing customers (Ringim, 2014; Aqib and Hussain, 2017; Belwal and Maqbali 2019).

The perceptions of stakeholders regarding Islamic banking objectives vary to a larger extent as Dusuki (2007) discussed in his study that customers, depositors and employees of Islamic banks perceive that the IB paradigm needs to focus more on the social objectives to follow the Shariah spirit in a true sense to ensure social welfare. Whereas the Shariah advisors, regulators and IB branch managers consider commercial objectives more important in order to survive and thrive in the face of the fierce competition by the conventional banking sector (Dusuki, 2008). The second point of view may be elucidate in the context of assertion made by Rosly and Bakar (2003) that it is a misconception to perceive Islamic banks as charitable entities because this is simply against the fundamental principle of business of any commercial enterprise to operate on benevolent basis without considering the profit motive. Khan and Ramzan (2015) also concluded that the stakeholders perceive that both social as well as commercial objectives are important for the Islamic banks to operate and flourish in comparison to the mighty rivalry posed by conventional banking sector.

\section{Methodology}

\section{Sampling}

Purposive sampling was employed because according to Van Rijnsoever (2015), purposive sampling is more efficient as compared to random sampling in the case of qualitative research as well as based on past 
research studies (Echchabi and Olaniyi, 2012; Echchabi and Aziz, 2014; Ayedh and Echchabi, 2015; Ali and Hassan, 2017); the researchers intended to conduct a total of 15 interviews but continued to expand sample size until the point of data saturation and finally 21 interviews in total were conducted.

\section{Data Collection}

The data was collected from semi-structured interviews being conducted from twelve Shariah scholars serving in Islamic banking sector and the nine staff members of State Bank of Pakistan (SBP).

\section{Data Analysis}

The data collected from the interview, in shape of recordings as well as notes taken during the interviews, was meticulously reviewed before the process of transcription. The data analysis was carried out with the formulation of themes in the context of key areas as discussed with the interviewees, entailing a profound reflection and interpretation of the collected data in order to acquire a comprehensive understanding of the meaning of the participants' experiences (Lester, 1999; Echchabi and Aziz, 2014).

\section{Findings and Discussion}

The interviewees included 12 Shariah experts serving in the Shariah boards of various Islamic banks and Islamic banking divisions of conventional banks. Furthermore, the interviewees also included the 9 central bankers serving in the Islamic banking department and IB focus groups operational in various regional and field offices of SBP. Both respondent groups were asked the same number of questions in the same order. The findings are further elaborated under the following main themes and their sub-themes.

\section{Islamic Banking Products and Services}

The interviewees were asked various questions about the various aspects pertaining to Islamic banking products/services including the features, their strengths, and competitiveness in comparison to the conventional banking products. The findings are elaborated under the following themes.

\section{Shariah Compliance}

Almost all the respondents mentioned that Shariah compliance is the most important element of all Islamic banking products and services. Majority of the respondents noted that this attribute not only differentiates Islamic banking products from the conventional services but is also an essential characteristic of the whole IB sector. The conformity with Shariah is conceived as a fundamental feature of IB offerings. This characteristic of IB products and services is the one that is most valued by the IB customers (Dusuki and Abdullah, 2007; Echchabi and Olaniyi, 2012; Echchabi and Aziz, 2014). In the opinion of interviewees from the pool of Shariah scholars, IB products are fully Shariah-compliant and the issue of Shariah compliance is among the top priorities of IB service providers. According to one of the interviewees (Interviewee 11) from the Shariah experts segment of respondents:

"[...] and Shariah compliance is not only the main feature but a necessary element in all offering of Islamic banking certifying that these products are free from riba (interest)."

Another interviewee from regulators group of respondents (Interviewee 16) said:

"Islamic banking services should and must be based on the basic principle of Shariah compliance and [...] other issues would take care of themselves if only the matter of Shariah compliance is ensured in all IB transactions and dealings". 
Several respondents opined that the basic difference between conventional and Islamic banking products is the characteristic of IB products being in consonance with Shariah guidelines and hence this is of cardinal significance for the customers who judge the services of IB entities mainly on the yardstick of Shariah conformity.

One of the interviewees (Interviewee 2) stated:

"[...] and there may be many factors that the customers of IB may consider while dealing with the Islamic banks but this is the one factor which tops the list of an overwhelming majority in my view."

Among the interviewees, one of the interviewee (Interviewee 19) opined that:

"[...] if we take out the basic factor of compliance with Shariah from the IB transactions, there is nothing except changed names and labels of IB products, so this single issue must be of paramount importance to all stakeholders including the service providers, practitioners, customers, Shariah supervisors and regulators".

This was beyond doubt that the respondents had unequivocal stance about the significance of Shariah compliance as the most considerable feature of Islamic banking products and services and they regarded it as the most vital factor that the Islamic banking customers consider while deciding to deal with Islamic banks, as highlighted in the studies by Abduh and Omar, (2012); Shakir and Lee, (2012); Echchabi et al., (2016); and Ltifi et al., (2016).

\section{Product Classification}

All Islamic banking products and services are based on Islamic legal and commercial concepts like Mudaraba, Ijarah and Salam etc. The interviewees had a sound understanding of IB product structures and based on their responses; following four product categories were gleaned:

(i) Equity-based participatory products designed on the basis of the concepts of Mudaraba, Muqarada, and Musharaka, mainly utilized for depository, equity-sharing and investment oriented offerings;

(ii) Lease-based products formulated on the basis of Ijarah and Ijahara Muntahiya Bitamleek, used as a financing tool to fund vehicles, consumer durables and home appliances;

(iii) Trade-based products structured on the basis of various modes of Shariah-compliant sales including Murabaha, Salam, Istisna, and Bai Bithaman Ajil, employed chiefly for financing of materials, fixed assets, business equipment and commodities etc.

(iv) Service-based products crafted on the Islamic legal concepts of Wakalah, Kafalah, Tawarruq, used for services like letters of credit (LCs), letters of guarantee, working-capital and liquidity financing, debit and credit cards etc.

The respondents had various versions of products and service classifications but all of them were similar in the sense that only the nomenclature and wording differed, but the contents of products they discussed were approximately the same as described above. The Shariah experts had a superior understanding of products as compared to the regulators as evidenced from the detailed responses of both respondent groups. Some of the responses of interviewees pertinent to product classes are elucidated below:

Interviewee 12: "IB products are Shariah-compliant services broadly of two kinds including equity-based involving Musharaka and Mudaraba structures [...] and debt-based products revolving around concepts like Murabaha, Salam and Istisna". 
Interviewee 18: "[...] products of IB include partnership-related products for deposit and checking accounts and some investment instruments, trade-related products like Murabaha and Istisna [...] and leasing products called Ijarah financing mainly for car financing and consumer financing needs of customers".

Interviewee 7: "[...] products and services are diverse with different kinds including Mudaraba, Musharaka, Diminishing Musharaka, Murabaha, [...] Salam, Istisna, Takaful, Ijarah etc. with varying utilization for investment and financing needs of clients.

The products as discussed by the respondents under various types and kinds were also discussed in the literature by Ayub, (2007); Hassan and Mahlknecht, (2011); Aqib and Hussain, (2016). The respondents described that debt-creating product structures of Islamic banks are not closer to Shariah spirit and hence there is a need to shift the focus towards equity-based and participatory modes of services founded on the principle of Musharaka and Mudaraba as these product structures are truly based on the principles of risksharing and are hence closer to Shariah in nature and spirit.

\section{Customer Orientation}

Interviewees when asked about Islamic banking services also emphasized the need to put customers in focus in the context of products designed and delivered to them. According to an interviewee (Interviewee 17):

“[...] and religious motive alone is not sufficient anymore to attract and retain the customers, in the competitive banking market and hence it is time to pay more attention to customer-oriented services and products".

One of the interviewees (Interviewee 3) responded to a question regarding Islamic banking services as under:

"[...] and gone are the days when Shariah-compliance was the only product attribute which the customers wished for, from the Islamic banking [...] and this is the right time to shift focus to more customer-driven services."

Some aspects that the respondents mentioned in relation to customer orientated Islamic banking products like customer convenience, courteous staff behavior and bank branch's environment etc, also came under discussion in some previous studies including the ones by Erol and EI-Bdour (1989); Dusuki and Abdullah (2007a); Shakir and Lee (2012), Ringim and Yussof (2014).

\section{Products Value and Service Competitiveness}

As discussed that apart from the fundamental underlying feature of Shariah compliance of IB products, other product attributes are also significant to the IB customers like cost effectiveness, use of technology, value-added services like ATMs, online and internet banking as discussed by Awan and Bukhari, 2011; Ringim, 2014; Butt et al., (2018). Butt and Aftab (2013) referred to this conception as functional beliefs regarding products in comparison to the religious beliefs that are only reliant upon Shariah compliance feature.

When the respondents of this study were asked about IB products and services, they stressed the need to focus the customers by offering products that besides being Shariah-compliant should also deliver customer value based on the inclusion of products attributes like risk sharing, cost competitiveness, value added services involving technology-driven services. One of the interviewees (Interviewee 21) stated: 
"IB customers like conventional banking customers expect value for their money when they transact with the Islamic banks and solely relying on Shariah or religious motive would not serve the cause of progressive Islamic banking industry [...]."

In the words of another respondent (Interviewee 14):

"This is extremely critical to attract and retain the customers [...] and Islamic banking must offer value to customers by delivering quality-based services in order to compete with the conventional banking products effectively because competitive markets demand competitive products to survive the stiff competition $[\ldots]$ '.

According to the majority of the research participants, customer-centric products are inevitable to survive and thrive in the cut-throat competition with the conventional banking and financial institutions and it is imperative for IB service providers to ensure that customers are delivered value-driven offerings that are not only Shariah-based but also pinned on the element of service quality to provide IB customers superior products which are competitive in comparison to the products of conventional banking.

\section{Product Development and Innovation}

Among other important matters, the issues of new product development and service innovation are considered pivotal for a sustainable and progressive IB paradigm, as per the viewpoint of several respondents. The matter was also highlighted in some of the previous literature by Aqib and Hussain, (2016); Ahmed, (2014); Ahmed, (2011). One of the interviewees (Interviewee 16) reported:

"There are several product related areas that need consideration [...] and one of the important issues is the lack of product diversity in the Islamic banking service assortment".

The respondents from Shariah scholars segment provided insightful opinions with reference to the issue of product development and innovation as stated hereunder:

Interviewee 4: "[...] and IB industry requires an efficient product research and development mechanism to cope with the dearth of innovative financial solutions that are not only Shariah-compliant but are also competitive as compared to the conventional banking offerings.".

Interviewee 8: "The process of new product development seeks attentions of all stakeholders to effectively address the matter of limited product choices for IB customers [...] and only Shariah experts cannot address the issue without the coordinated effort from other vital components of IB structure including the regulators, senior bank management and other relevant decision taking authorities within and outside Islamic banks".

Interviewee 10: "[...] and Shariah experts are the forefront of this aspect of developing and approving new products and services [...] and this is absolutely crucial for a successful and sustainable IB industry.

The regulators also shared their views about the scarcity of product options and lack of variety in IB services and emphasized the significance of product diversity and innovation by stating that among other factors, narrow product range of Islamic banks is one of the major issues behind the slack growth of the IB industry.

\section{Islamic Banking Objectives}

The topic of Islamic banking objectives has been an important aspect of IB paradigm as the foundations of Islamic banking model are laid upon Shariah objectives but critics claim that there is somewhat a conflict 
and a mismatch between Islamic banking business/commercial objectives and the Shariah as well as the social objectives (Khan, 2010; Mansoori, 2011; Visser, 2019). The respondents provided their responses regarding the three dimensions of Islamic banking objectives as discussed hereunder.

\section{Shariah Objectives}

An overwhelming majority of the research participants from the group of Shariah experts opined that Shariah objectives are at the top of the list from among the three categories of IB objectives i.e. Shariah, business and social objectives. Whereas, the respondents from the regulators segment were of the view that Shariah objectives are vital though not the top priority of Islamic banking and financial institutions. For reference, some of the statements of interviewees are reproduced here:

Interviewee 1: "The first and foremost are Shariah objectives [...] and if Shariah objectives are achieved, other goals can be taken care of with greater effectiveness".

Interviewee 9: "Shariah goals are paramount for the Islamic banks and other objectives both business as well as social are subsidiary to Shariah objectives".

Interviewee 20: "There is no doubt that Shariah objectives are on the top of the list for Islamic banks [...] and there may be debate regarding the significance of commercial objectives in comparison to Shariah objectives but it is incumbent upon the Shariah scholars at Islamic banks' SSBs to ensure a balance between the various facets of IB objectives $[\ldots]$ ".

The respondents from both groups agreed on the importance of Shariah objectives especially in the context of vitality of Shariah objectives in the viewpoint of customers, as also highlighted by Dusuki, (2007); Dusuki and Abdullah, (2007a); Echchabi and Aziz, (2014); however regulators disagreed that Shariah objectives are the first concern of Islamic banks while Shariah scholars asserted that Shariah objectives are at the helm of all business decisions in the Islamic banking entities.

\section{Business and Commercial Objectives}

The respondents from the set of IB regulators expressed that like conventional banks, Islamic banks are also commercial entities and hence the top aim of Islamic banks is the fulfillment of business objectives and not the Shariah objectives. They opined that being profit-oriented enterprises, the commercial goals of Islamic banks, take precedence over Shariah and social goals. The statements of three of the interviewees are mentioned here:

Interviewee 6: "Islamic banks are not charity organizations and hence based on profit motive, this is unnatural to consider that Islamic banks would only focus on Shariah objectives and would not pursue business goals to earn profits".

Interviewee 13: "[...] and Islamic banks products, at times are expensive than conventional banks which denotes that business objectives are deemed superior than Shariah and social objectives for Islamic banking organizations".

Interviewee 19: "This is certainly clear that business objectives are dearer to the decision makers at Islamic banks $[\ldots]$ and they are entrusted to maximize shareholders' profits; so this is quite obvious that the Islamic banking and financial enterprises are bound to place business goals before all other agendas."

The interview respondents from each segment noted that business objectives are an integral component of Islamic banks' organizational goals, yet this is essential that Shariah objectives are not being compromised for business objectives. Furthermore, this is the responsibility of management and Shariah board members 
to ensure that business goals are not pursued at the cost of Shariah objectives (Grassa, 2013); as SSB members are the ones charged with overseeing and monitoring the IB transactions and practices to assess violations of any Shariah guidelines (IFSB, 2006; Ayedh and Echchabi, 2015).

\section{Social Objectives}

With reference to the significance of social objectives, the respondents had varying opinions. Most of them were of the view that social objectives are beyond the domain of Islamic banks and hence Islamic banks are only supposed to take care of Shariah and business objectives and let the social objectives be dealt by the state. Some responses are given here to elaborate the stance of participants:

Interviewee 5: "[...] and Islamic banks should not be perceived to be the ones playing the role of social welfare entities because they are business oriented establishments and it is not their function to worry about social welfare matters."

Interviewee 15: "Social goals are not the direct concern of Islamic banking and financial institutions [...] rather Islamic banks are indirectly contributing towards the social wellbeing by being financial intermediaries that generate economic activity to boost economic progress of the people."

Some of the interviewees opined that Islamic banks are enjoined to attain social objectives by contributing towards the social welfare of general people and they related the concept of corporate social responsibility (CSR) to the aspect of social objectives as discussed in studies by Dusuki and Abdullah, (2007b). In this regard, one of the interviewees (Interviewee 6) said:

"[...] and Islamic banks are involved in various charitable and social welfare activities, also there are some charity organizations being funded and sponsored by Islamic banks reflecting that Islamic banking entities are playing their due role in terms of social welfare objectives".

The discussion can be summed up by concluding that Islamic banks are not only supposed to achieve the business goals neglecting the social welfare dimension entirely, as also elucidated by Dusuki, (2008); Majeed and Zainab, (2017) and Butt et al., (2018).

\section{Conclusion}

The discussion about products and services entailed discourse on various dimensions pertinent to Islamic banking products and service issues and respondents agreed that Shariah compliance is the fundamental attribute of all IB offerings yet the participants emphasized the need to focus on customer-centric products delivering value and services quality to customers, as highlighted by Dusuki and Abdullah 2007a; Loo, 2010; Awan and Bukhari, 2011; Shakir and Lee 2012, Ringim and Yussof 2014; Butt and Aftab 2013; Butt et al., 2018. While discussing about aspects of product development and innovation, findings were similar to those of Ahmed, 2014; Aqib and Hussain, 2016 stressing upon greater efforts to innovate and develop diverse IB products. With reference to IB objectives, Shariah objectives were considered to be the top priority of Islamic banks according to Shariah members of SSBs but IB regulators noted that business goals are at the forefront instead of Shariah goals. The respondents also had the viewpoint that social objectives are not under the scope and capacity of Islamic banking as against the notion commonly held that social objectives must be assumed as a major issue by Islamic banking institutions (Dusuki, 2007; Dusuki, 2008). Based on the responses, this may be concluded that Shariah compliant products alone cannot warrant sustainable success of IB paradigm; hence this is crucial to focus on IB product development domain to bring diverse, innovative and value-based products and services that may lift the IB industry in comparison to the mighty conventional banking system and help IB sector to blossom and achieve its true potential. 


\section{References}

Abduh, M. and Omar, M.A. (2012), "Islamic-bank selection criteria in Malaysia: an AHP approach", Business Intelligence Journal, Vol. 5 No. 2, pp. 271-281.

Abdullah, A.K.M.A. and Kassim, N.M. (2009), "Measuring perceived service quality in Qatari Islamic banks", J. International Business and Entrepreneurship Development, Vol. 4 Nos 1/2, pp. 90-106.

Ahmad, N. and Haron, S. (2002). Perceptions of Malaysian Corporate Customers Towards Islamic Banking Products and Services, International Journal Of Islamic Finance Services, 3(1), 13-29.

Ahmed, H. (2014). Islamic banking and Shari'ah compliance: a product development perspective. Journal of Islamic finance., 3(2), 15-29.

Ahmed, H. (2014). Islamic banking and Shari'ah compliance: a product development perspective. Journal of Islamic finance., 3(2), 15-29.

Ahmed, Habib, (2011) Product Development in Islamic Banks. Edinburgh University Press.

Akhtar, Naeem, Mehmood, Muhammad Toqeer, and Pervez, Muhammad Zeeshan, Talat (2016), Factors Influencing the Perception of Customers in Islamic Banking: A Case Study in Pakistan, International Review of Management and Business Research, Volume, Issue 3.

Ali, S. A., \& Hassan, A. (2017). Employees' attitude towards Islamic banking: an exploratory study in Malaysia. International Journal of Research in Social Sciences, 7(4), 114-138.

Ali, S., Hassan, A., Juhdi, N., \& Razali, S. (2018). Employees' attitude towards Islamic banking: measurement development and validation. Humanomics, 34(1), 78-100.

Aqib Ali, Muhammad (2014). Evolution \& Development of Islamic Banking: The Case of Pakistan. European Journal of Islamic Finance, Volume 1, Issue 1.

Aqib Ali, Muhammad and Hussain, Talat (2016). Equity Based Islamic Finance: A Product Development Perspective. Journal of Global Business and Social Entrepreneurship, 119-127.

Aqib Ali, Muhammad and Hussain, Talat (2017), Murabaha Perceptions of Islamic Bankers, Case of Pakistan, COMSATS Journal of Islamic Finance (CJIF), Volume 2, Issue 2, ISSN 2519-707X.

Awan, H.M. and Bukhari, K.S, (2011),"Customer's criteria for selecting an Islamic bank: evidence from Pakistan", Journal of Islamic Marketing, Vol. 2 Iss: 1 pp. 14 - 27

Awan, H.M., Bukhari, K.S. and Iqbal, A. (2011), "Service quality and customer satisfaction in the banking sector: a comparative study of conventional and Islamic banks in Pakistan", Journal of Islamic Marketing, Vol. 2 No. 3, pp. 203-224.

Ayedh, A. M., \& Echchabi, A. (2015). Shari'ah supervision in the Yemeni Islamic banks: a qualitative survey. Qualitative Research in Financial Markets, 7(2), 159-172.

Ayub, M. (2007). Understanding Islamic finance. Wiley Finance Series, John Wiley \& Sons Ltd, The Atrium, Southern Gate, Chichester, West Sussex PO19 8SQ, England.

Ayub, M. (2017). Liquidity Management by Islamic Banks: An Issue or a Contrivance for Risk-Free Returns. Journal of Islamic Business \& Management, 7(1), 1-10.

Belwal, R., \& Al Maqbali, A. (2019). A study of customers' perception of Islamic banking in Oman. Journal of Islamic Marketing.

Buchari, I., Rafiki, A., \& Al Qassab, M. A. H. (2015). Awareness and attitudes of employees towards islamic banking products in Bahrain. Procedia Economics and Finance, 30, 68-78.

Butt, I., Ahmad, N., Naveed, A., \& Ahmed, Z. (2018). Determinants of low adoption of Islamic banking in Pakistan. Journal of Islamic Marketing, 9(3), 655-672.

Butt, I., Saleem, N., Ahmed, H., Altaf, M., Jaffer, K., \& Mahmood, J. (2011). Barriers to adoption of Islamic banking in Pakistan. Journal of Islamic Marketing, 2(3), 259-273.

Butt, M.M. and Aftab, M. (2013), "Incorporating attitude towards Halal banking in an integrated service quality, satisfaction, trust and loyalty model in online Islamic banking context", International Journal of Bank Marketing, Vol. 31 No. 1, pp. 6-23.

Denscombe, M. (2005). The Good Research Guide: for Small-Scale Social Research Projects $\left(2^{\text {nd }}\right.$ ed.). Philadelphia: Open University Press.

Dusuki, A. W., \& Abdullah, N. I. (2007b). Maqasid al-Shariah, Maslahah, and Corporate Social Responsibility. American Journal of Islamic Social Sciences, 24(1), 25-45. 
Dusuki, A.W. (2007) The Ideal of Islamic Banking: A Survey of Stakeholders' Perceptions, Review of Islamic Economics, Vol. 11, Special Issue, 2007, pp 29-52.

Dusuki, A.W., \& Abdullah, I.N. (2007a) Why do Malaysian customers patronise Islamic banks? International Journal of Bank Marketing, 25(3), 142-160.

Dusuki, A.W., (2008) "Understanding the objectives of Islamic banking: a survey of stakeholders' perspectives", International Journal of Islamic and Middle Eastern Finance and Management, Vol. 1 Iss: 2, pp. $132-148$.

Echchabi, A., \& Aziz, H. A. (2014). Shari'ah issues in Islamic banking: A qualitative survey in Malaysia. Qualitative Research in Financial Markets, 6(2).

Echchabi, A., \& Olaniyi, O. N. (2012). Malaysian consumers' preferences for Islamic banking attributes. International journal of social economics.

Echchabi, A., Azouzi, D. and Aziz, H.A. (2016), "The future prospects of Islamic banking in Tunisia: an empirical survey", EuroMed Journal of Business, Vol. 11 No. 1, pp. 119-131.

Elbeck, M. and Dedoussis, E.V. (2010), "Arabian Gulf innovator attitudes for online Islamic bank marketing strategy", Journal of Islamic Marketing, Vol. 1 No. 3, pp. 268-285.

Erol, C. and EI-Bdour, R. (1989), "Attitudes, behaviour, and patronage factors of bank customers towards Islamic banks", International Journal of Bank Marketing, Vol. 7 No. 6, pp. 31-37.

Fada, Kodun Abiah, and Webekwa, BundiEl Sheikh, (2012)," People's Perception Towards Islamic Banking: A Field work study in Gombe Local Government Area, Nigeria", International Journal of Business, Humanities and Technology, Vol. 2 No. 7; December 2012

Gerrard, P. and Cunningham, J.B. (1997), "Islamic banking: a study in Singapore”, International Journal of Bank Marketing, Vol. 15 No. 6, pp. 204-216.

Grassa, R. (2013). Shariah supervisory system in Islamic financial institutions New issues and challenges: a comparative analysis between Southeast Asia models and GCC models. Humanomics, 29(4), 333-348.

Hassan, K., \& Mahlknecht, M. (2011). Islamic capital markets: Products and strategies (Vol. 609). John Wiley \& Sons.

IFSB, Islamic Financial Services Board (2019), Islamic Financial Services Industry: Stability Report 2019, Kuala Lumpur, Malaysia.

IFSB. (2006). Guiding principles on corporate governance for institutions offering only Islamic financial services (excluding Islamic insurance (takaful) institutions and Islamic mutual funds). Kuala Lumpur: Malaysia.

Iqbal, Zamir and Mirakhor, Abbas (2007). An Introduction to Islamic Finance: Theory and Practices. John Wiley \& Son Pte, Ltd, Singapore, 2007.

Jose, S., Khare, N., \& Buchanan, F. (2018). Customer perceptions of CSR authenticity. International Journal of Organizational Analysis, 26(4), 614-629.

Khan, F. (2010), "How 'Islamic' is Islamic banking?", Journal of Economic Behavior and Organization, Vol. 76 No. 3, pp. 805-820.

Khan, M.M, and Ramzan M. (2015). Perceptions of Stakeholders on Islamic Banking in Pakistan. Journal of Islamic Business and Management, 3(2), 159-194.

Khan, M.S.N., Hassan, M.K. and Shahid, A.I. (2007), "Banking behaviour of Islamic bank customers in Bangladesh", Islamic Economics, Banking and Finance, Vol. 3 No. 2, pp. 159-194.

Lee, Kun-ho and Shakir Ullah, (2011) "Customers' attitude toward Islamic banking in Pakistan", International Journal of Islamic and Middle Eastern Finance and Management, Vol. 4 Iss: 2, pp.131 145.

Lester, S (1999) 'An introduction to phenomenological research,' Taunton UK, Stan Lester Developments.

Loo, M. (2010). Attitudes and perceptions towards Islamic banking among Muslims and non-Muslims in Malaysia: implications for marketing to baby boomers and x-generation. International Journal of Arts and Sciences, 3(13), 453-485.

Ltifi, M., Hikkerova, L., Aliouat, B. and Gharbi, J. (2016), "The determinants of the choice of Islamic banks in Tunisia", International Journal of Bank Marketing, Vol. 34 No. 5, pp. 710-730.

Lujja, S., Mohammed, M., \& Hassan, R. (2018). Islamic banking: an exploratory study of public perception in Uganda. Journal of Islamic Accounting and Business Research, 9(3), 336-352. 
Majeed, M. T., \& Zainab, A. (2017). How Islamic is Islamic banking in Pakistan?. International Journal of Islamic and Middle Eastern Finance and Management, 10(4), 470-483.

Mansoori, M. T. (2011). Is" Islamic Banking" Islamic? Analysis of current debate on Sharīah legitimacy of Islamic banking and finance. Islamic Studies, 383-411.

Metawa, S. A. and Almossawi, M. (1998). ),"Banking behavior of Islamic bank customers: perspectives and implications", International Journal of Bank Marketing, Vol. 16 Iss: 7 pp. 299 - 313

Riaz, U. A. (2014), "Perceptions and Experiences of British-based Muslims on Islamic Banking and Finance in the UK". A Thesis Submitted for Degree of Doctor of Philosophy, University of Dundee, Dundee, UK.

Ringim K. J. and Yussof I. M. (2014) 'Perception, Awareness And Understanding Of Muslim Account Holders In Conventional Banks With Respect To Patronising Islamic Banking Products In Nigeria”, Ilorin Journal of Economic Policy, Vol.1, No.1: 41-52.

Ringim, K.J. (2014), "Perception of Nigerian Muslim account holders in conventional banks toward Islamic banking products", International Journal of Islamic and Middle Eastern Finance and Management, Vol. 7 No. 3, pp. 288-305.

Rosly, S.A. and Bakar, M.A.A. (2003), "Performance of Islamic and mainstream banks in Malaysia", International Journal of Social Economics, Vol. 30 No. 12, pp. 1249-65.

Rustam, S., Bibi, S., Zaman, K., Rustam, A., \& Haq, Z. U. (2011). Perceptions of corporate customers towards Islamic banking products and services in Pakistan. The Romanian Economic Journal, 41(4), 107-123.

Saeed Akbar, Syed Zulfiqar Ali Shah, Shahin Kalmadi, (2012) "An investigation of user perceptions of Islamic banking practices in the United Kingdom", International Journal of Islamic and Middle Eastern Finance and Management, Vol. 5 Iss: 4, pp.353 - 370

Saidi, T.A. (2009), "Relationship between ethical and Islamic banking systems and its business management implications" South African Journal of Business Management, Vol. 40 No. 1, pp. 43-49.

Shah, B.A, Niazi, G.S.K and Abdul Majid, (2016),"Employees’ Perceptions about Islamic Banking and its Growth Potential in Pakistan", Business \& Economic Review: Vol. 8, Issue 1: 2016 pp. 53-76.

Shakir, U. and Lee, K.H. (2012), "Do customers patronize Islamic banks for Sharia compliance", Journal of Financial Services Marketing, Vol. 17 No. 3, pp. 206-214

Shome, A., Jabeen, F., \& Rajaguru, R. (2018). What drives consumer choice of Islamic banking services in the United Arab Emirates?. International Journal of Islamic and Middle Eastern Finance and Management, 11(1), 79-95.

Souiden, N. and Rani, M. (2015), "Consumer attitudes and purchase intentions toward Islamic banks: the influence of religiosity", International Journal of Bank Marketing, Vol. 33 No. 2, pp. 143-161.

State Bank of Pakistan - SBP (2019), Islamic Banking Bulletin (IBB) December, 2019.

State Bank of Pakistan - SBP (2020), Islamic Banking Bulletin (IBB) March, 2020.

Thomson Reuters (TR). (2018), Islamic Finance Development Report 2018 by Shereen Mohamed, Abdulaziz Goni and Shaima Hasan.

Usmani, Muhammad Taqi (1999), Islamic Finance, New Steps, Darul Uloom, Karachi.

Van Rijnsoever, F. J. (2015). (I Can't Get No) Saturation: A Simulation and Guidelines for Minimum Sample Sizes in Qualitative Research. Innovation Studies Utrecht (ISU) Working Paper Series, 15(05), $1-25$.

Visser, H. (2019). The Islamic economy: its origin, its world view and its claims. The Central European Review of Economics and Management, 3(4), 53-89.

Wilson, R. (2005), "Parallels between Islamic and ethical banking", Journal of Islamic Banking and Finance, Vol. 22 No. 3, pp. 85-97. 